\title{
Accruals, cash flows and earnings in european privately held firms
}

Borja Amor Tapia ${ }^{1}$

borja.amor@unileon.es

Ma Teresa Tascón Fernández

m.tascon@unileon.es

Universidad de León

\section{Resumen}

Este trabajo examina las propiedades de los ajustes al devengo, los flujos de caja y los resultados en las empresas europeas no cotizadas. A partir de varias hipótesis sobre la persistencia de los resultados y sus componentes, encontramos que las empresas no cotizadas parecen comportarse de forma diferente a la evidencia encontrada previamente sobre las empresas cotizadas. Las diferencias son significativas cuando los ajustes al devengo son extremos, dado que la persistencia del ROA y de los flujos de caja siguen patrones de comportamiento distintos a los encontrados en las empresas estadounidenses cotizadas. Pero contrariamente a nuestras hipótesis, las diferencias en la persistencia no son significativas cuando las empresas no cotizadas publican resultados positivos frente a resultados negativos.

Palabras clave: Empresas no cotizadas; Propiedades del resultado; Ajustes al devengo; Flujos de caja.

\section{Abstract}

This paper examines the properties of accruals, cash flows and earnings in European privately held firms. We start from several hypotheses about the persistence of earnings and its components, finding that private companies seem to behave in a different manner than the publicly traded firms tested in previous literature. As hypothesized, differences are significant when accruals are extreme, though in European private firms, persistence of ROA relative to cash flow follows a different pattern than in US public firms. But contrary to our expectations, differences in persistence are not significant when companies report positive versus negative earnings.

Keywords: Private companies; Earnings properties; Accruals; Cash flows.

${ }^{1}$ Departamento de Dirección y Economía de la Empresa, Facultad de Ciencias Económicas y Empresariales, Universidad de León, Campus de Vegazana, 24071-León (España). 


\section{INTRODUCTION}

In fundamental analysis and valuation, the commonly used discounted cash flow approach requires the analysts to make several predictions about the future performance and investment opportunities of the firm, to avoid structural inconsistencies in their forecasts. The earning-based methods frame the issues in terms of accounting data. So that, accounting variables are typically the analysts' primary forecasts and they have to dedicate considerable time to analyze historical financial accounts.

Accounting variables build on accrual accounting while the discounted cash flow approach tries to undo the accruals, spreads the resulting cash flows over longer horizons, and then reconstructs its own "accruals" in the form of discounted expectations of future cash flows. As Palepu et al. (2000, p. 11-18) say, "the usefulness of the accounting-based perspective hinges on how well the accrual process reflects future cash flows», even though an unbiased accrual process is the most convenient approach.

A research line has studied the performance of earnings-based valuation relative to discounted cash flow and other discounting methods. The findings (Penman and Sougiannis, 1998; Francis et al., 2000) indicate that over relatively short forecast horizons, ten years or less, valuation estimates using the earnings approach generate more precise estimates of value than discounted cash flow models. And this advantage for the earnings-based approach persists for firms with conservative or aggressive accounting, indicating that accrual accounting in the U.S. does a reasonably good job of reflecting future cash flows.

But forecasts are possible only if the analysts can find the regularity of cash flows, for what it is necessary that previously they "normalize" earnings. Due to it, recent research has focused on the persistence of incomes, both accounting earnings and its underlying cash flows. The difference between them, the accruals, have become an important indicator of earnings quality that is useful for equity valuation. Sloan (1996) documents the existence of a negative relationship between accounting accruals and subsequent stock returns ('accrual anomaly'). Large positive accruals indicate that cash flows are much lower than the earnings generated by the firm. The difference arises because of accounting conventions as to when, and how much, revenues and costs are recognized (the so-called "revenue recognition" and "matching" principles).

Since the paper of Sloan, a growing body of literature has provided evidence that higher accruals relative to the cash flow component of earnings is associated with lower earnings persistence in the following year. However, until now most of the related research tests the US listed companies. Very few works focus on firms from outside US, and still less use samples consisting of unquoted firms.

Our work tries to fill this gap, examining the evolution of the earnings components: accruals and cash flows, in a wide sample of European privately held firms. The persistence of ROA, cash flows and accruals is analyzed in-depth. 
In private firms, the absence of capital markets as reference is an inherent difficulty, increased by the absence of tools to reduce the uncertainty around the estimates of future earnings. For this reason, we try to shed light on the effects of adjustments to the cash flows (accruals) in privately held European firms. The European setting provides a unique opportunity to analyze the properties of cash flows, accruals and earnings when capital markets are relatively small and firms tend to obtain financing mainly from the bank system. Until now, accounting in Europe, especially in the case of non quoted firms, is conditioned by the firm's legal form and tax rules play an important role in financial reporting (Burgstahler et al., 2006; Coppens and Peek², 2005).

The paper adds to the growing body of evidence on earnings management, and earnings, cash flows and accruals persistence, but from a different perspective. The paper extends both types of studies to European firms and it is, up to our knowledge, the first research work to present evidence on private firms in earnings persistence. In addition, our study explores the relation of income (earnings, accruals and cash flows) persistence to an institutional factor: the legal origin.

To achieve our objectives we run several regression analyses. Financial information of all European private firms with available data is extracted from Amadeus Database and information on the legal origin from Shleifer's Database.

The results indicate that earnings management is a general practice in European private firms: managers use accruals to smooth earnings too. But we document that the income persistence pattern for private firms is different from the one for the US public firms previously tested: in the extreme accruals, ROA's persistence is higher than Cash Flows'. Besides, contrary to our expectations, persistence seems not to be different when profits versus losses are obtained. In these two aspects, our study casts doubt on the extent to which earlier findings generalize outside the US traded companies. Finally, legal origin does not appear as a relevant structural factor in European private firms' persistence among the three (French, German and Scandinavian) groups of countries considered.

The rest of the study is structured as follows: the next section provides a review of literature related to previous research on income (earnings, cash flows and accruals) persistence; Section 3 develops the research hypotheses; Section 4 provides details on sample selection and variable measurement; Section 5 shows descriptive statistics and

2 This paper addresses the questions of whether private firms in eight European countries engage in earnings management, and if so, whether tax incentives affect such practices. The empirical evidence suggests that in absence of capital market pressures, in general, firms still have incentives to manage earnings in order to avoid reporting small losses. But in some countries where tax regulation strongly influences financial accounting, private firms do not avoid reporting small losses. The authors infer that some types of earnings management are due to capital market pressures and are specific to public firms, while tax incentives reduce private firms' benefits of (upward) earnings management. We have not included this work among previous evidence works on earnings quality measured by accruals (next section) because it uses a different methodology to measure earnings management, they analyze the earnings distributions of private firms and compare these distributions with those of public firms in the same countries. 
persistence estimations, presenting the results of the empirical tests; and Section 6 sums up and concludes.

\section{PREVIOUS EVIDENCE ON EARNINGS QUALITY MEASURED BY ACCRUALS}

Several wide strands of literature are related to this work: discounted cash flow valuation, valuation models comparison, accrual accounting versus cash flow accounting and so on. But in this section we just allude to a number of references directly concerned with accounting accruals as an indicator of earnings quality.

Papers on earnings quality focus in the implementation of strategies that exploit predictable changes in future earnings performance resulting from accounting distortions. So that, long positions are taken in securities for which increases in earnings performance are estimated and short positions are taken in the opposite situation. The seminal work of Sloan (1996) shows that the accrual component of earnings is less persistent than the cash flow component of earnings, but that stock prices are not able to anticipate this effect. As high (low) accruals are indicative of aggressive (conservative) accounting, the author documents significant returns to a very basic earnings quality strategy.

Numerous studies support the evidence found in Sloan (1996), documenting the fewer persistence of the accrual component respect to the cash flow component of earnings. That is, a higher proportion of accrued relative to cash earnings (low-quality earnings) is associated with lower earnings performance in the subsequent fiscal year (for instance, Chan et al., 2004 y 2006). However, researchers do not agree on the explanation for this result:

1) one stream of literature put this result down to accounting distortions (Xie 2001; Dechow and Dichev 2002; McNichols 2002; Richardson et al. 2005; Richardson et al. 2006).

2) a second stream attributes it to a more general growth effect and argues that growth-related factors such as diminishing returns to new investment explain the lower persistence of accruals (e.g., Fairfield et al. 2003; Dechow and Ge 2006).

In the first stream, interpretations suggest earnings management signals. Higher levels of operating accruals relative to cash flows act as a sign of a subsequent earnings reversal. Xie (2001) shows that results documented in Sloan -the lower earnings persistence and the returns to the accrual trading strategy- are driven by abnormal accruals (ie. accruals that are unrelated to changes in the underlying level of operating activity). This measure is derived by orthogonalizing Sloan's original measure of accruals with respect to sales growth. Thus, 'normal' accruals that are driven by growth in operating activity are removed. The remaining abnormal accruals are more likely to reflect transitory accounting distortions. However, since most of the variation in accruals is assigned to abnormal accruals, the returns to the trading strategy based on abnormal 
accruals are of about the same magnitude as the returns using Sloan's original accrual trading strategy.

Dechow and Dichev (2002) model earnings quality as the magnitude of estimation errors in accruals, and provide empirical estimates of this construct based on the relation between accruals and cash flows. The new measure is based on one aspect of the quality of working capital accruals and earnings. As one role of accruals is to shift or adjust the recognition of cash flows over time, the authors propose that the adjusted numbers (earnings) better measure firm performance. Assuming that the quality of accruals and earnings is decreasing in the magnitude of estimation error in accruals, they derive an empirical measure of accrual quality as the residuals from firm-specific regressions of changes in working capital on past, present, and future operating cash flows. Dechow and Dichev document that observable firm characteristics can be used as instruments for accrual quality (e.g., volatility of accruals and volatility of earnings). Finally, they show that their measure of accrual quality is positively related to earnings persistence.

McNichols (2002) characterizes the innovation and limitations in Dechow and Dichev (2002) approach, and provide empirical evidence of measurement error in their empirical specification. In this work, their model is adapted to assess the specification of the Jones' (1991) model and results document that this model provides estimates of discretionary accruals that are significantly associated with cash flows, which are likely to be substantially nondiscretionary.

Richardson et al. (2006) provide new evidence indicating that temporary accounting distortions are a significant contributing factor to the lower persistence of the accrual component of earnings. And their evidence shows that the lower persistence of accruals extends to accruals that are unrelated to sales growth and that extreme accruals are systematically associated with alleged cases of earnings manipulation.

As for the second stream of literature, Fairfield et al. (2003) suggest that the accrual effect in Sloan (1996) is at least partly due to the fact that accruals signify an increase in (less-productive) net operating assets. In this way, the author contributes to the discussion with a double point of view: accruals have effects both on income statements and balance sheets. Up to this study earnings performance was typically defined as oneyear-ahead operating income divided by one-year-ahead invested capital, or a measure of profitability, but they find that accruals are more highly associated than cash flows with invested capital in the denominator of the profitability measure. In contrast, accruals and cash flows have no differential relation to one-year-ahead operating income. The evidence is not consistent with accruals having a reversal effect on earnings, rather, it suggests that the lower persistence of accruals versus cash flows may be due to the effect of growth on future profitability.

In a sample of US public companies, Dechow and Ge (2006) find that earnings are more persistent than cash flows in high accrual firms, due to the growth of firms. If the firm is growing, allowable accruals adjustments are likely to reduce the effect of negative 
transitory cash flows on earnings, and consistent with this prediction, high accrual firms have high earnings persistence relative to that of cash flows.

Some other works have extended Sloan's (1996) methodologically. Closed to the line followed by Fairfield et al. (2003) Hribar and Collins (2002) examine the impact of measuring accruals as the change in successive balance sheet accounts, as opposed to measuring accruals directly from the statement of cash flows. Their primary finding is that studies using a balance sheet approach to test for earnings management are potentially contaminated by measurement error in accruals estimates. In particular, if the partitioning variable used to indicate the presence of earnings management is correlated with the occurrence of mergers and acquisitions or discontinued operations, tests are biased and researchers are likely to erroneously conclude that earnings management exists when there is none. Additional results show that the errors in balance sheet accruals estimation can confound returns regressions where discretionary and nondiscretionary accruals are used as explanatory variables. Moreover, the authors demonstrate that tests of market mispricing of accruals will be understated due to erroneous classification of "extreme" accruals firms.

Richardson et al. (2005) extend the work of Sloan (1996) in two ways: first, they include investing and financing accruals and show that these new accruals add significantly to the forecasting ability with respect to earnings persistence and future stock returns; second, they construct a model to link accrual reliability to earnings persistence. Empirical tests develop a comprehensive balance sheet categorization of accruals and rate each category according to the reliability of the underlying accruals, generally confirming that less reliable accruals lead to lower earnings persistence and that investors do not fully anticipate the lower earnings persistence (security mispricing). These results suggest that there are significant costs associated with incorporating less reliable accrual information in financial statements.

The quality of earnings is related to conservative accounting by Penman and Zhang (2002). In this work, temporary distortions in earnings are caused by investment growth (like in the second stream of literature previously mentioned) but interacting with conservative accounting. The process is as follows: under conservatism, growth in investment reduces reported earnings and creates reserves; reducing investment releases those reserves, increasing earnings; if the change in investment is temporary, then current earnings is temporarily depressed or inflated, and thus is not a good indicator of future earnings. The study develops diagnostic measures of this joint effect of investment and conservative accounting, and finds that these measures forecast differences in future return on net operating assets relative to current return on net operating assets. Moreover, these measures also forecast stock returns-indicating that investors do not understand the temporary nature of these distortions.

The Dechow and Ge's (2006) work, mentioned before as a representative of the second stream of literature following Sloan, pay attention to accounting rules from a different view point. They argue that high accruals are likely to be the outcome of rules with an income statement perspective, while low accruals are likely to be the outcome of rules with a balance sheet perspective, and that this has implications for the properties of earnings. Specifically, earnings persistence is affected both by the magnitude and sign of the accruals. Accruals improve the persistence of earnings relative to cash flows in high 
accrual firms, but reduce earnings persistence in low accrual firms. They show that the low persistence of earnings in low accrual firms is primarily driven by special items. In their results, special item-low accrual firms have higher future stock returns than other low accrual firms. This is consistent with investors misunderstanding the transitory nature of special items. Further analysis reveals that special item-low accrual firms have poor past performance and declines in investor recognition (analyst coverage and institutional holdings).

In the most recent studies, the negative relationship between accounting accruals and subsequent stock returns has been named as "the accruals anomaly". Desai et al. (2004) relates it with the glamour stock phenomenon. Computing operating cash flows as earnings adjusted for depreciation and working capital accruals, scaled by price (CFO/P), they capture mispricing attributed to the four traditional value-glamour proxies and accruals. Interpretation of this finding depends on the reader's priors. If the reader believes that value-glamour phenomenon can be operationalized only as $C / P$, and not $\mathrm{CFO} / \mathrm{P}$, then one would conclude that CFO/P is a parsimonious variable that captures the mispricing attributes of two distinct anomalies, value glamour and accruals. However, if a reader views the value-glamour anomaly broadly as a fundamentals-to-price anomaly, then (1) the CFO/P variable can be considered an expanded value-glamour proxy and; (2) the results are consistent with Beaver's (2002) conjecture that the accruals anomaly is the glamour stock phenomenon in disguise.

Although the accruals anomaly is an empirical regularity documented in the academic and practitioner literatures -for almost a decade, as this section shows-, it seems that sophisticated investors have not manage to learn about it and arbitrage the anomaly away. Lev and Nissim's (2006) study shows that the accruals anomaly still persists as a market inefficiency and its magnitude has not declined over time. While institutional investors seem to react promptly to accruals information, it is clear that their reaction is rather weak and is primarily characteristic of active investors who constitute a minority of institutions. Lev and Nissim put it down to a main reason: extreme accruals firms have characteristics which are unattractive to most institutional investors, and individual investors are by and large unable to profit from trading on accruals information due to the high transaction and information costs associated with implementing a consistently profitable accruals strategy. Consequently, the accruals anomaly persists, and will probably endure.

The geographical extension of the accruals anomaly is studied in Pincus et al. (2007). Considering stock markets in 20 countries they investigate whether the accrual anomaly is a local manifestation of a global phenomenon. Their findings indicate that stock prices overweight accruals in general, with accruals overweighting occurring in countries with a common law relative to a code law tradition. They document the occurrence of the anomaly in four countries, Australia, Canada, the U.K., and the U.S., and also in a sample of American Depository Receipts (ADRs) of firms domiciled in countries where they do not detect the anomaly. Using country-level data, the analysis confirms the anomaly is more likely to occur in countries having a common law tradition, and also in countries allowing extensive use of accrual accounting and having a lower concentration of share ownership. Additional analyses reveal that earnings management and barriers to arbitrage best explain the anomaly. 
Finally, we include in this compilation the study of Chan et al. (2004) because they document the consequences of earnings manipulation. This paper examines how current accruals affect future earnings (the accrual effect) and measures the size of this effect. Aggregate future earnings seem to get decreased by $\$ 0.046$ and $\$ 0.096$, respectively, in the next one and three years for a $\$ 1$ increase of current accruals. Over the very longterm (25 years), $20 \%$ of current accruals is reversed. This negative accrual effect is more significant for firms with high price-earnings ratios, high market-to-book ratios and high accruals where earnings management is more likely to occur. Incorporating the accrual effect proves to be useful in improving the accuracy of earnings forecasts for these firms. Accordingly, the empirical results are consistent with the notion that earnings management causes the negative relationship between current accruals and future earnings.

\section{HYPTOTHESIS DEVELOPMENT}

Private companies are different from public companies at various levels. First, requirements about information in financial reports are not the same for private and public companies, as National Securities Agencies usually require more information more frequently. So that, disclosure level should be lower for private companies (not interested in giving more information than the strictly mandatory one). Second, private companies tend to have lower levels of ownership dispersion, that is why principal-agent conflicts between owners and managers are mitigated.

In private held firms, managers can have different disclosure (and earnings management) motivations than in quoted companies, so earnings, accruals and cash flows likely present different levels of persistence. According to the evidence found by Dechow and Ge (2006), when high accrual firms are growing earnings are more persistent than cash flows. The authors suggest that adjustments are made likely to reduce the effect of negative transitory cash flows on earnings. Our first hypothesis treats to check if European private firms follow this general pattern: in high accrual firms, are earnings more persistent than cash flows?

H1: In European private firms earnings are more persistent than cash flows in high accrual firms

Following the reasoning proposed by Dechow and Ge (2006), the more assets and liabilities that accounting rules mark to fair value, the more earnings will reflect changes in fair value, and so the lower the persistence of earnings. Considering that, until recent years, accounting in European code law countries had less assets and liabilities marked to fair value than in common law countries, our second hypothesis goes against the Dechow and Ge findings. Even now private companies can disclose information using national GAAPs which strongly rely on historical costs. 
H2: In European private firms earnings are more persistent than cash flows in low accrual firms

As previous research shows, accrual and cash flow components of current earnings have different implications for the assessment of future earnings. Current earnings performance is less likely to persist if it is attributable primarily to the accrual component of earnings. This leads us to the Sloan (1996) findings in public companies, our third hypothesis:

H3: The persistence of current earnings performance in private firms is decreasing in the magnitude of the accrual component of earnings and increasing in the magnitude of the cash flow component of earnings

Finally, we think that managers' motivation to make accruals is different when a firm is in a good situation or in a bad one. It makes sense that earnings management is a common practice considering the advantages of regular gains and the disadvantages of irregular gains. Market takes net income's lack of variability as one of the main signals of stability, reliability, strengthening,... following the idea that variability means risk. But when a firm obtains/gets losses, even occasionally, it is undoubtedly a signal of bad news for the market. For that, one of the main concerns is giving a not-so-bad image of the firm's situation and accruals contribute to compensate negative numbers significantly. This intention would emphasize the earnings management effect asymmetrically, making higher the incentive to manage earnings trying to compensate negative figures than the incentive to compensate "excessive" gains. Evidence found by Burgstahler and Dichev (1997) and Hayn (1995) support this reasoning for quoted companies but we set up our fourth hypothesis for private firms in order to find out if this type of firms suffer the same type of pressure when disclosing financial information.

Hayn (1995) finds that losses are less informative than profits about the firm's future prospects because shareholders have a liquidation option. In a related work, Burgstahler and Dichev (1997) provide evidence that quoted firms manage reported earnings to avoid earnings decreases and losses. They find unusually low frequencies of small decreases in earnings and small losses and unusually high frequencies of small increases in earnings and small positive income. Also, they find evidence that two components of earnings, cash flow from operations and changes in working capital, are used to achieve increases in earnings. If earnings are managed, we can expect that firms with negative earnings show more negative and volatile cash flows than firms with positive earnings. As a result, the persistence of ROA and cash flows in firms with positive earnings should be higher than in firms with negative earnings. Our fourth hypothesis is:

H4: In European private firms with positive earnings, cash flows are more persistent than in firms with negative earnings 


\section{RESEARCH DESIGN}

In this section we explain the testing process of our hypotheses about the extent of persistence of earnings, cash flows and accruals. For that, details are included on sample selection, measurement variables and results of the several types of regressions run.

\subsection{Sample selection}

Our sample consists of all non quoted European firms on Amadeus database for the period 1995 to 2006, for which necessary data are available. We start selecting quoted and non quoted firms for both consolidated and unconsolidated accounts (code C2/U2), which totalizes 64,825 observations corresponding to 22,215 firms. As our analysis is restricted to non quoted firms, we exclude quoted firms' observations. Besides, we remove those firm-year observations in which some necessary information to compute the primary financial statement variables used in our test is missing. The final sample is made up of 12.910 non quoted firms, from 18 European countries (53.581 observations). (Database update: february 2007) Additional information, on the legal origin, has been obtained from Shleifer's Database.

\subsection{Measurement variables}

In this study we run several regression analyses in order to find out the persistence of net income and its two divisions: the part in cash and that one totalizing accruals. Thus, the explanatory variables include current ROA, accruals, cash flows, profits/losses and legal origin.

We define ROA as after tax net income, whether profit or loss (coded 'PLAT' in Amadeus) deflacted by contemporaneous total assets (Amadeus Code: TOAS). Accruals and cash flows are scaled by total assets, too, as to control variables for firm scale. In fact, to compute Cash Flows, we apply an income statement approach, using the expression:

Deflacted Earnings $=$ Deflacted Accruals + Deflacted Cash Flows

Following Sloan (1996) we define accruals as:

Accruals $=(\triangle \mathrm{CUAS}-\triangle \mathrm{CASH})-(\triangle \mathrm{CULI}-\triangle \mathrm{LOAN}-\triangle \mathrm{TAXA})-\mathrm{DEPR}$

Where

$\triangle \mathrm{CUAS}=$ change in current assets,

$\triangle \mathrm{CASH}=$ change in cash $\&$ cash equivalents,

$\triangle \mathrm{CULI}=$ change in current liabilities,

$\triangle \mathrm{LOAN}=$ change in debt included in current liabilities,

$\triangle T A X A=$ change in income taxes payable, and

$D E P R=$ depreciation and amortization expense. 


\section{RESULTS}

\subsection{Descriptive statistics}

In this section, we provide descriptive statistics of ROA, accruals and cash flows over the sample of European non quoted firms. Table 1 provides statistics on the characteristics of the sample. Average ROA is 0.03 while average cash flow is 0.07 . This difference reflects the fact that due to depreciation (and perhaps earnings management), accruals are negative (-0.04). Total Assets (toas) and Sales (turn) show a great dispersion, reflecting the differences in size between firms in the sample.

Table 1

Sample desc niptives

\begin{tabular}{lcrrrr}
\hline Variable & Obs & Mean & Std. Dev. & Min & \multicolumn{1}{c}{ Max } \\
\hline ROA & 53,570 & 0.0300 & 0.6008 & -137.1207 & 5.6160 \\
ACCR & 53,581 & -0.0476 & 2.5363 & -458.1488 & 236.9833 \\
CFLW & 53,570 & 0.0776 & 2.6054 & -236.9583 & 458.1488 \\
toas & 53,581 & 293,331 & $1,935,084$ & 120 & $111,000,000$ \\
tum & 53,453 & 245,971 & $1,142,055$ & 0 & $58,200,000$ \\
\hline
\end{tabular}

Table 2 shows the mean values of each variable for the 18 countries considered. As the second column $-\mathrm{N}(\mathrm{ROA})$ - shows, each country representation in the sample is very heterogenous, from a unique observation for some countries (Denmark, Luxemburg, Malta), to several thousands for others, being Sweden the country with the highest number of observations. Except for the case of Germany, on average ROA has been positive. With respect to Cash Flows, all countries show positive values, generally higher than ROAs, being indicative of using accruals as a general mechanism to smooth earnings.

The average firm size per country, measured as total assets, also presents wide dipersion, being Germany the country with the biggest firms. 


\section{Table 2 \\ Descriptives by country}

\begin{tabular}{|c|c|c|c|c|c|}
\hline country & N(ROA) & mean(ROA) & mean(ACCR) & mean(CRW) & mean(toas) \\
\hline AUSTRIA & 101 & 0.025 & -0.055 & 0.080 & 689810 \\
\hline BELG IUM & 2,855 & 0.021 & -0.053 & 0.075 & 423006 \\
\hline BULGARIA & 2 & 0.035 & -0.123 & 0.158 & 3650 \\
\hline C 正CH REPUBபC & 2 & 0.053 & 0.018 & 0.034 & 515168 \\
\hline DENMARK & 1 & 0.040 & -0.024 & 0.064 & 22445 \\
\hline FINLAND & 5,066 & 0.060 & -0.039 & 0.099 & 98812 \\
\hline FRANCE & 8,062 & 0.028 & -0.050 & 0.079 & 459644 \\
\hline GERMANY & 3,115 & -0.011 & -0.074 & 0.063 & 875501 \\
\hline ICELAND & 92 & 0.044 & -0.045 & 0.089 & 75329 \\
\hline ITALY & 9,490 & 0.014 & -0.062 & 0.076 & 292418 \\
\hline LATVIA & 11 & 0.090 & -0.044 & 0.134 & 136571 \\
\hline LUXEMBOURG & 1 & 0.011 & 0.007 & 0.004 & 170153 \\
\hline MALTA & 1 & 0.062 & -0.057 & 0.119 & 312267 \\
\hline POLAND & 796 & 0.027 & -0.050 & 0.077 & 108112 \\
\hline PORTUGAL & 684 & 0.008 & -0.044 & 0.052 & 399901 \\
\hline SLOVAKIA & 22 & 0.016 & -0.125 & 0.141 & 73612 \\
\hline SPAIN & 6,636 & 0.037 & -0.058 & 0.095 & 342195 \\
\hline SWEDEN & 16,633 & 0.038 & -0.030 & 0.069 & 125521 \\
\hline Total & 53,570 & 0.030 & -0.048 & 0.078 & 293331 \\
\hline
\end{tabular}

Firm-years are ranked annually and assigned in equal numbers to the ten deciles. Figure 1 depicts the means of accruals, cash flows and ROA. The mean value of cash flows falls from 0.41 for the lowest accrual portfolio to -0.19 for the highest accrual portfolio. In contrast, accruals grow from -0.45 to 0.25 . The consequence is a quite steady mean value of earnings (ROA): lightly increasing from -0.03 , for the lowest accrual portfolio, up to 0.05 , for the highest accrual portfolio. In this figure, earnings smoothing can be appreciated clearly. 


\section{Figure 1}

\section{Averages by deciles of eamings, cash flows and ac cruals}

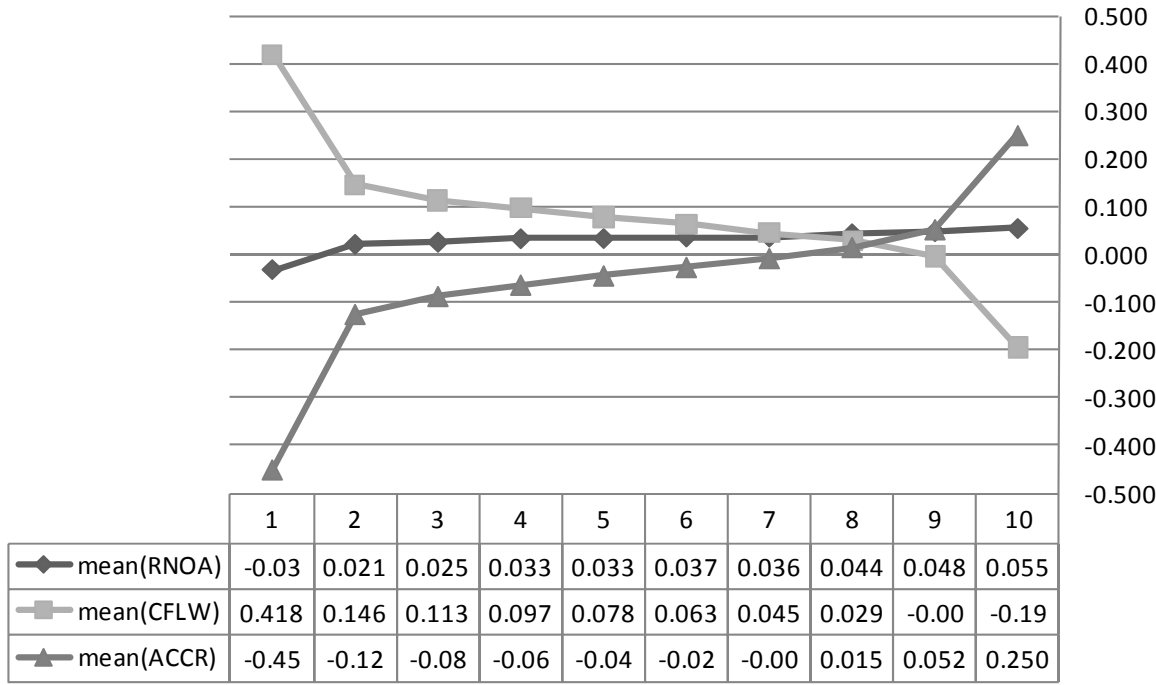

Table 3 provides Spearman correlations. Consistent with prior research in quoted firms, we document a positive (although weak) correlation between ROA and accruals $(0.18$, for the contemporaneous period, and lesser, 0.09, for the following one). We also document a positive correlation between ROA and cash flows $(0.37$ for the contemporaneous year, and a lighter 0.28 for the following one). These results reflect a stronger correlation between ROA and cash flows than between ROA and accruals, suggesting that cash flows are more relevant components of earnings, that is to say, the weighting of accruals is not so relevant in earnings. But the strongest relation is the negative one between cash flows and accruals.

\section{Table 3}

\section{Speaman comelations}

\begin{tabular}{|c|c|c|c|c|c|c|}
\hline & fROA & ROA & ACCR & CFW & toas & tum \\
\hline fROA & 1 & & & & & \\
\hline ROA & $0.6704 *$ & 1 & & & & \\
\hline ACCR & 0.0969* & 0.1809* & 1 & & & \\
\hline CFW & $0.2859 *$ & $0.3785^{*}$ & $-0.7697^{*}$ & 1 & & \\
\hline toas & $-0.1713^{*}$ & $-0.1601^{*}$ & $-0.0311 *$ & $-0.0549 *$ & 1 & \\
\hline tum & $-0.0771^{*}$ & $-0.0556 *$ & $-0.0464 *$ & $0.0120 *$ & 0.8296* & 1 \\
\hline
\end{tabular}




\subsection{Persistence of cash flows (H1) and accruals (H2)}

Prior studies in quoted companies show that the persistence of ROA relative to cash flows varies with the magnitude of accruals. To investigate this issue we rank observations each year into deciles based on each measure of accruals. Decile 1 contains firms with extreme negative accruals (extreme positive cash flows) and decile 10 includes firms with extreme positive accruals (extreme negative cash flows). We then perform the following regressions for each decile:

[1b] Cash Flows ${ }_{t+1}=\gamma_{0}+\gamma_{1}$ Cash Flows $_{\mathrm{t}}+v_{t+1}$

[1c] $\quad \mathrm{ROA}_{\mathrm{t}+1}=\gamma_{0}+\gamma_{1}$ Cash Flows $_{\mathrm{t}}+v_{t+1}$

Regressions (1a) and (1b) examine whether the persistence of ROA and Cash Flows is lower for extreme accrual deciles. Regression (1c) addresses the question of whether future earnings are better predicted by earnings or cash flows by providing evidence on how well cash flows predict future earnings across deciles.

Figure 2 depicts the estimated persistence parameter of ROA and cash flows based on the magnitude of accruals. On average, ROA is more persistent than cash flows, which is consistent with evidence found by previous research (Dechow, 1994, Dechow and Ge, 2006), that finds that revenue recognition rules and the matching principle improve earnings as a measure of performance relative to cash flows.

As previous research shows in quoted companies, the persistence of ROA displays a concave relation with accruals. Large accruals of either sign reduce the persistence of ROA. This is consistent with the findings reported in previous research with samples of quoted companies. So that, our study shows that findings reported in previous research with samples of quoted companies can be generalized to other types of firms, such as private non quoted firms, at least in Europe.

\section{Eamings and cash flow persistence for future firm performance, by rank of accruals}

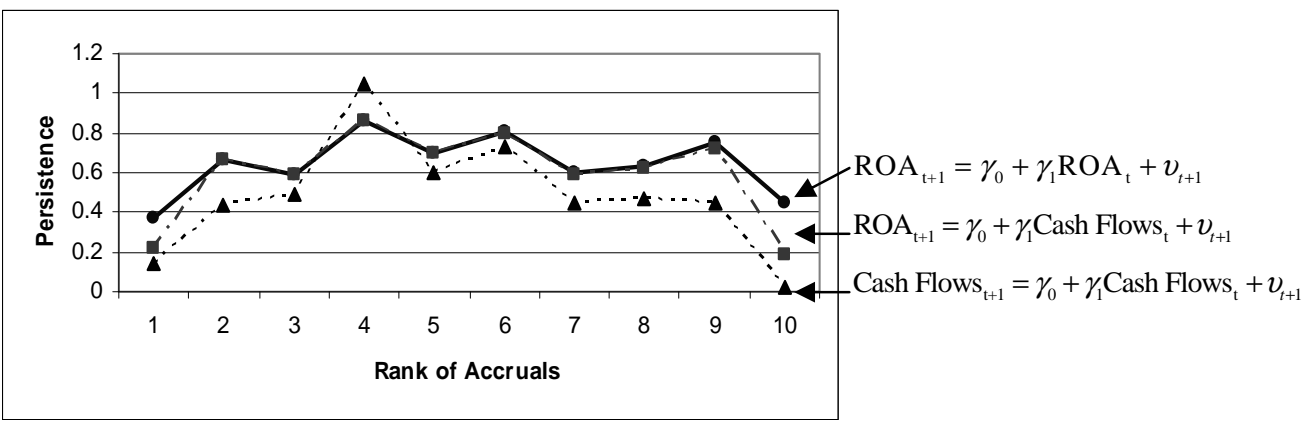


The persistence of cash flows also reflects a concave pattern, suggesting that underlying economics reflected in accruals also affect the persistence of cash flows. However, contrary to Dechow ad Ge's (2006) findings for US listed companies, non quoted European firms show higher persistence of ROA than that of Cash Flows in the extreme accruals.

Our result indicates that, for this type of firms, earnings smoothing help to approach the business' regular income, even when accruals are extreme (whether positive or negative). Curiously, cash flows have the same prediction power than ROA for predicting one-yearahead ROAs, except in both types of extreme accrual firms, for which cash flows are clearly less useful than ROA.

\subsection{Persistence of earnings, cash flows and accruals ( $H 3$ )}

The third hypothesis is that earnings performance attributable to the accrual component of earnings is less persistent than earnings performance attributable to the cash flow component of earnings. To this contrast, Sloan (1996) regresses future profitability, defined as one-year-ahead ROA (income from continuing operations deflated by average total assets), on the accrual and cash flow deflated components of current ROA. The specification implied by $\mathrm{H} 3$ is:

$$
\operatorname{ROA}_{t+1}=\gamma_{0}+\gamma_{1} \text { Accruals }_{t}+\gamma_{2} \text { Cash Flows }_{t}+v_{t+1}
$$

Tests of $\mathrm{H} 3$ are displayed in Table 4. Panel A provides Fama-MacBeth regressions by deciles of ROA, while Panel B provides regressions using the disaggregation of ROA into both components: accruals and cash flows.

The results in Panel A indicate that the persistence parameter of ROA is 0.47 in the pool regression, showing a concave pattern by accrual deciles. After decomposing ROA into cash flows and accruals, the cash flow component of earnings (0.47) is more persistent than the accrual component of earnings (0.45). The smaller coefficient on accruals relative to cash flows, $\gamma_{1}<\gamma_{2}$, reflects the lower persistence of earnings performance attributable to the accrual component of earnings.

Consistent with the results obtained for the previous test, the predictive power of cash flows is bigger than the same for accruals. 
Table 4

Fama-MacBeth regressions by accruals size

PANEL A

\begin{tabular}{lrrrrrr}
\hline & Pool & Lowest & Decile 20 & Decile 30 & Decile 40 & Decile 50 \\
\hline ROA & $0.474^{* * *}$ & $0.375^{* * *}$ & $0.663^{* * *}$ & $0.590^{* * *}$ & $0.863^{* * *}$ & $0.702^{* * *}$ \\
& {$[0.071]$} & {$[0.090]$} & {$[0.048]$} & {$[0.076]$} & {$[0.041]$} & {$[0.14]$} \\
\hline Intercept & $0.0199^{* * *}$ & $0.0282^{* * *}$ & $0.0139^{*}$ & $0.0132^{* * *}$ & $0.00769^{* *}$ & -0.00944 \\
& {$[0.0034]$} & {$[0.0063]$} & {$[0.0063]$} & {$[0.0041]$} & {$[0.0027]$} & {$[0.016]$} \\
\hline Observations & 38901 & 3660 & 3875 & 3918 & 3855 & 3810 \\
Number of years & 11 & 11 & 11 & 11 & 11 & 11 \\
R-squared & 0.23 & 0.27 & 0.32 & 0.42 & 0.52 & 0.47 \\
\hline & \multicolumn{7}{c}{} & & & & & & \\
\hline & Decile 60 & Decile 70 & Decile 80 & Decile 90 & Highest \\
\hline ROA & $0.804^{* * *}$ & $0.604^{* * *}$ & $0.629^{* * *}$ & $0.758^{* * *}$ & $0.446^{* * *}$ \\
& {$[0.043]$} & {$[0.11]$} & {$[0.073]$} & {$[0.072]$} & {$[0.093]$} \\
\hline Intercept & $0.00495^{*}$ & 0.0204 & $0.0201^{* *}$ & $0.0101^{* *}$ & $0.0246^{* * *}$ \\
& {$[0.0025]$} & {$[0.012]$} & {$[0.0082]$} & {$[0.0044]$} & {$[0.0043]$} \\
\hline Observations & 3946 & 3956 & 3960 & 4008 & 3913 \\
Number of years & 11 & 11 & 11 & 11 & 11 \\
R-squared & 0.52 & 0.38 & 0.40 & 0.50 & 0.29 \\
\hline
\end{tabular}

PANEL B

\begin{tabular}{lrrrrrr}
\hline & Pool & Lowest & Decile 20 & Decile 30 & Decile 40 & Decile 50 \\
\hline Accruals & $0.453^{* * *}$ & $0.336^{* * *}$ & $0.754^{* *}$ & $0.540^{* *}$ & 0.755 & 0.0952 \\
& {$[0.067]$} & {$[0.076]$} & {$[0.32]$} & {$[0.21]$} & {$[0.53]$} & {$[0.79]$} \\
\hline Cash Flows & $0.477^{* * *}$ & $0.382^{* * *}$ & $0.673^{* * *}$ & $0.587^{* * *}$ & $0.874^{* * *}$ & $0.694^{* * *}$ \\
& {$[0.072]$} & {$[0.093]$} & {$[0.050]$} & {$[0.075]$} & {$[0.047]$} & {$[0.14]$} \\
\hline Intercept & $0.0189^{* * *}$ & $0.0174^{*}$ & 0.0270 & 0.0101 & 0.00492 & -0.0347 \\
& {$[0.0035]$} & {$[0.0088]$} & {$[0.036]$} & {$[0.012]$} & {$[0.032]$} & {$[0.041]$} \\
\hline Observations & 38901 & 3660 & 3875 & 3918 & 3855 & 3810 \\
Number of years & 11 & 11 & 11 & 11 & 11 & 11 \\
R-squared & 0.23 & 0.27 & 0.33 & 0.42 & 0.52 & 0.47 \\
\hline
\end{tabular}

\begin{tabular}{lrrrrr}
\hline & Decile 60 & \multicolumn{1}{c}{ Decile 70 } & Decile 80 & \multicolumn{1}{c}{ Decile 90 } & \multicolumn{1}{c}{ Highest } \\
\hline Accruals & $1.298^{* *}$ & 0.972 & 0.219 & $0.790^{* * *}$ & $0.428^{* * * *}$ \\
& {$[0.49]$} & {$[0.55]$} & {$[1.02]$} & {$[0.13]$} & {$[0.13]$} \\
\hline Cash Flows & $0.803^{* * *}$ & $0.593^{* * *}$ & $0.634^{* * *}$ & $0.755^{* * *}$ & $0.461^{* * *}$ \\
& {$[0.042]$} & {$[0.12]$} & {$[0.073]$} & {$[0.070]$} & {$[0.089]$} \\
\hline Intercept & 0.0194 & 0.0324 & 0.0186 & 0.0107 & $0.0312^{* * *}$ \\
& {$[0.014]$} & {$[0.024]$} & {$[0.018]$} & {$[0.0064]$} & {$[0.0095]$} \\
\hline Observations & 3946 & 3956 & 3960 & 4008 & 3913 \\
Number of years & 11 & 11 & 11 & 11 & 11 \\
R-squared & 0.52 & 0.39 & 0.41 & 0.50 & 0.33 \\
\hline
\end{tabular}

Standard emors in brackets; *** $p<0.01$, ** $p<0.05, * p<0.1$; Independent Variable: RO $A_{t+1}$.

We next examine the conjecture that firms reporting losses shows different persistence in the accrual and cash flow component than firms with positive net income. 


\subsection{Persistence and the sign of net income ( $\mathrm{H} 4)$}

Table 5 shows descriptive statistics by the sign of net income and the magnitude of accruals. In the case of firms with positive earnings, average ROA is 0.05 while average cash flow is 0.09 and average accruals are negative (only the three top deciles shows positive accruals). Firms reporting losses show negative ROAs but positive cash flows, while accruals are negative. The magnitudes of Total Assets indicate that there is no difference in terms of firm size across deciles.

Table 5

Descriptives by the sign of net income and ac cruals size

\begin{tabular}{|c|c|c|c|c|c|}
\hline $\begin{array}{c}\text { Net Income and } \\
\text { Accruals }\end{array}$ & N(RNOA) & mean(RNOA) & mean(ACCR) & mean(CRW) & mean(toas) \\
\hline \multicolumn{6}{|l|}{ Positive } \\
\hline Lowest Acc. & 3,326 & 0.0548355 & -0.5399265 & 0.5949745 & 328707.05 \\
\hline 2 & 3,859 & 0.0490817 & -0.1244664 & 0.1735362 & 254896.85 \\
\hline 3 & 4,075 & 0.0461557 & -0.0873751 & 0.1335308 & 287711.21 \\
\hline 4 & 4,342 & 0.0474553 & -0.0635351 & 0.1109843 & 307955.26 \\
\hline 5 & 4,426 & 0.0454504 & -0.0443879 & 0.0898383 & 324089.21 \\
\hline 6 & 4,529 & 0.0484335 & -0.0265951 & 0.0750286 & 417851.55 \\
\hline 7 & 4,602 & 0.0480205 & -0.0081381 & 0.0561554 & 358806.54 \\
\hline 8 & 4,735 & 0.0536489 & 0.015152 & 0.0384929 & 215782.22 \\
\hline 9 & 4,765 & 0.0607482 & 0.0526075 & 0.0081408 & 182069.89 \\
\hline Highest Acc. & 4,630 & 0.0753136 & 0.2557632 & -0.1804496 & 246737.03 \\
\hline Total & 43,289 & 0.0531227 & -0.0405855 & 0.0936964 & 290983.54 \\
\hline \multicolumn{6}{|l|}{ Negative } \\
\hline Lowest Acc. & 1,882 & -0.1901894 & -0.2962615 & 0.1060722 & 206554.52 \\
\hline 2 & 1,491 & -0.0527209 & -0.1286464 & 0.0759255 & 192260.39 \\
\hline 3 & 1,300 & -0.0397895 & -0.0894812 & 0.0496917 & 301458.98 \\
\hline 4 & 949 & -0.0341926 & -0.0658813 & 0.0316887 & 297313.13 \\
\hline 5 & 873 & -0.0295075 & -0.0463049 & 0.0167974 & 349171.76 \\
\hline 6 & 854 & -0.0259718 & -0.0277649 & 0.0017962 & 741549.2 \\
\hline 7 & 820 & -0.0287821 & -0.00945 & -0.0193321 & 407648.61 \\
\hline 8 & 656 & -0.0291873 & 0.0126291 & -0.0418164 & 234041.97 \\
\hline 9 & 684 & -0.0399238 & 0.0508623 & -0.0907861 & 145662.25 \\
\hline Highest Acc. & 772 & -0.0676792 & 0.2155793 & -0.2832586 & 313414.09 \\
\hline Total & 10,281 & -0.0672078 & -0.0768949 & 0.0096922 & 303217.88 \\
\hline
\end{tabular}


To test our fourth hypothesis, we run the following regression:

$$
\begin{aligned}
\mathrm{ROA}_{\mathrm{t}+1} & =\gamma_{0}+\gamma_{1} \mathrm{ROA}_{\mathrm{t}}+\gamma_{2} \text { Accruals }_{\mathrm{t}}+\gamma_{3} \text { Cash Flows }_{\mathrm{t}}+\gamma_{4} D+ \\
& +\gamma_{5}\left(\mathrm{D} \times \mathrm{ROA}_{\mathrm{t}}\right)+\gamma_{6}\left(\mathrm{D} \times \text { Accruals }_{\mathrm{t}}\right)+\gamma_{7}\left(\mathrm{D} \times \text { Cash Flows }_{\mathrm{t}}\right)+v_{t+1}
\end{aligned}
$$

where $D$ is a dummy variable equal to one for firms reporting losses. This regression investigates whether the coefficients of ROA, accruals and cash flows are different when the firm reports positive versus negative earnings. Table 6 reports the results of our regressions. Surprisingly, we don't find differences between firms with positive and negative earnings. There is no difference in the persistence of ROA, accruals and cash flows between firms, rejecting our fourth hypothesis.

Contrary to our ex-ante expectations, there are no significant differences in the persistence of cash flows, accruals or NOA when firms get profits or losses. It means no asymmetrical behaviour of managers in managing earnings when the figures are positive versus negative.

Table 6

Losses vs. profits. Fama-Mac Beth regressions by acc ruals size

\begin{tabular}{lrrrrrr}
\hline & Pool & \multicolumn{1}{c}{ Lowest } & Decile 20 & Decile 30 & Decile 40 & Decile 50 \\
\hline ROA & $0.286^{* *}$ & $0.377^{* * *}$ & $0.430^{* *}$ & $0.276^{*}$ & $0.651^{* *}$ & $\begin{array}{r}0.496^{* *} \\
\end{array}$ \\
& {$[0.093]$} & {$[0.11]$} & {$[0.14]$} & {$[0.15]$} & {$[0.24]$} & {$[0.17]$} \\
\hline ACCR & $0.227^{* *}$ & 0.0805 & $0.444^{* *}$ & 0.100 & -0.247 & -0.876 \\
& {$[0.090]$} & {$[0.10]$} & {$[0.15]$} & {$[0.087]$} & {$[0.49]$} & {$[0.70]$} \\
\hline CFLW & $0.255^{* *}$ & 0.111 & $0.298^{* *}$ & $0.300^{* *}$ & 0.244 & -0.0856 \\
& {$[0.086]$} & {$[0.095]$} & {$[0.12]$} & {$[0.12]$} & {$[0.23]$} & {$[0.34]$} \\
\hline D & $-0.0223^{* * *}$ & -0.0535 & 0.242 & 0.0106 & 0.0472 & -0.0139 \\
& {$[0.0051]$} & {$[0.039]$} & {$[0.20]$} & {$[0.049]$} & {$[0.032]$} & {$[0.035]$} \\
\hline dROA & -0.0743 & -0.117 & 2.811 & 0.682 & -0.390 & -0.670 \\
& {$[0.071]$} & {$[0.13]$} & {$[3.33]$} & {$[0.62]$} & {$[0.23]$} & {$[0.46]$} \\
\hline dACCR & -0.0809 & -0.107 & 1.327 & -0.207 & 0.481 & 0.484 \\
& {$[0.092]$} & {$[0.14]$} & {$[1.44]$} & {$[0.19]$} & {$[0.35]$} & {$[0.62]$} \\
\hline dCFLW & -0.0823 & -0.0337 & -0.686 & 0.0122 & -0.212 & 1.076 \\
& {$[0.076]$} & {$[0.13]$} & {$[0.86]$} & {$[0.21]$} & {$[0.28]$} & {$[0.66]$} \\
\hline Constant & $0.0194^{* * *}$ & $0.0265^{*}$ & $0.0364^{*}$ & -0.00053 & -0.0243 & -0.0357 \\
& {$[0.0041]$} & {$[0.014]$} & {$[0.019]$} & {$[0.0072]$} & {$[0.032]$} & {$[0.034]$} \\
\hline Observations & 38901 & 3660 & 3875 & 3918 & 3855 & 3810 \\
Number of groups & 11 & 11 & 11 & 11 & 11 & 11 \\
R-squared & 0.28 & 0.37 & 0.40 & 0.45 & 0.54 & 0.50 \\
\hline
\end{tabular}

\begin{tabular}{lrrrrr}
\hline & Decile 60 & Decile 70 & Decile 80 & Decile 90 & \multicolumn{1}{c}{ Highest } \\
\hline ROA & $1.289^{*}$ & 0.516 & 0.799 & $0.369^{* *}$ & $0.183^{*}$ \\
& {$[0.59]$} & {$[0.37]$} & {$[0.55]$} & {$[0.15]$} & {$[0.089]$} \\
\hline ACCR & 0.140 & 0.748 & -0.572 & $0.347^{* * *}$ & 0.238 \\
& {$[0.14]$} & {$[0.66]$} & {$[0.93]$} & {$[0.096]$} & {$[0.16]$} \\
\hline CFLW & -0.466 & 0.0947 & -0.196 & $0.362^{* *}$ & $0.312^{* *}$ \\
& {$[0.62]$} & {$[0.33]$} & {$[0.58]$} & {$[0.13]$} & {$[0.13]$} \\
\hline
\end{tabular}




\begin{tabular}{lrrrrr}
\hline $\mathrm{D}$ & -0.0427 & -0.0236 & 0.0177 & $-0.0237^{* *}$ & $-0.0376^{*}$ \\
& {$[0.026]$} & {$[0.025]$} & {$[0.035]$} & {$[0.010]$} & {$[0.018]$} \\
\hline $\mathrm{dROA}$ & -1.849 & -0.173 & -0.192 & 0.444 & -0.0159 \\
& {$[1.12]$} & {$[0.18]$} & {$[0.31]$} & {$[0.34]$} & {$[0.19]$} \\
\hline $\mathrm{dACCR}$ & 0.152 & -0.2 & -0.871 & 0.176 & -0.300 \\
& {$[0.38]$} & {$[0.48]$} & {$[2.11]$} & {$[0.27]$} & {$[0.28]$} \\
\hline $\mathrm{dCFLW}$ & $1.865 *$ & 1.141 & 0.222 & -0.242 & -0.337 \\
& {$[1.02]$} & {$[1.30]$} & {$[0.31]$} & {$[0.22]$} & {$[0.27]$} \\
\hline Constant & 0.0216 & 0.0331 & 0.0213 & $0.0159^{* *}$ & $0.0371^{* *}$ \\
& {$[0.017]$} & {$[0.029]$} & {$[0.020]$} & {$[0.0061]$} & {$[0.012]$} \\
\hline Observations & 3946 & 3956 & 3960 & 4008 & 3913 \\
Number of & & & & & \\
groups & 11 & 11 & 11 & 11 & 11 \\
R-squared & 0.56 & 0.42 & 0.43 & 0.54 & 0.42 \\
\hline
\end{tabular}

Standard errors in brackets; *** $p \varangle 0.01, * * p<0.05, * p<0.1$.

$\mathrm{ROA}_{\mathrm{t}+1}=\gamma_{0}+\gamma_{1} \mathrm{ROA}_{\mathrm{t}}+\gamma_{2}$ Accruals $_{\mathrm{t}}+\gamma_{3}$ Cash Flows $_{\mathrm{t}}+\gamma_{4} D+\gamma_{5}\left(\mathrm{D} \times \mathrm{ROA}_{\mathrm{t}}\right)+\gamma_{6}\left(\mathrm{D} \times\right.$ Accruals $\left._{\mathrm{t}}\right)+\gamma_{7}\left(\mathrm{D} \times\right.$ Cash Flows $\left._{\mathrm{t}}\right)+v_{t+1}$

The analysis in Table 6 suggests that changes in the sign of net income do not influence in the persistence of earnings components. To check these results we make additional regressions controlled by legal origin.

\subsection{Evidence from legal origin}

A growing stream of research, 'The Law View' holds that historically determined differences in national legal traditions continue to shape cross-country differences in property rights. In general, commercial laws come from two broad traditions: common law (English in origin) and civil law (derived from Roman law). Within the civil tradition, there are three families: French, German and Scandinavian, and the resulting laws reflect the influence of their families and the individual country revisions.

Countries with poorer investor protection, measured by both the character of legal rules and the quality of law enforcement, have smaller and narrower capital markets (La Porta et al., 1997). In particular, French civil law countries have both the weakest investor protection and the least developed capital markets (both equity and debt), especially as compared to common law countries.

Leuz et al. (2003) show an endogenous link between corporate governance and the quality of reported earnings. They examine systematic differences in earnings management across 31 countries based on the notion that insiders, in an attempt to protect their private control benefits, use earnings management to conceal firm performance from outsiders. Thus, earnings management decreases in investor protection because strong protection limits insiders' ability to acquire private control benefits, which reduces their incentives to mask firm performance.

Thus, according to previous research we explore the existence of differences in persistence across legal origins. Table 7 provides descriptives by legal origin 


\section{Table 7 \\ Desc riptives by legal origin}

\begin{tabular}{llrrrrr}
\hline \multicolumn{1}{c}{ Legal origin } & variable & \multicolumn{1}{c}{ obs } & mean & \multicolumn{1}{c}{ median } & \multicolumn{1}{c}{ min } & \multicolumn{1}{c}{ max } \\
\hline fren & ROA & 27,729 & 0.0244 & 0.0222 & -1.9913 & 1.7578 \\
& ACCR & 27,729 & -0.0562 & -0.0350 & -458.1488 & 236.9833 \\
& CFLW & 27,729 & 0.0806 & 0.0607 & -236.9583 & 458.1488 \\
\hline \multirow{2}{*}{ ger } & ROA & 4,049 & -0.0025 & 0.0200 & -137.1207 & 5.6160 \\
& ACCR & 4,049 & -0.0693 & -0.0555 & -26.5665 & 8.7168 \\
& CFLW & 4,049 & 0.0668 & 0.0790 & -136.8793 & 26.5794 \\
\hline scan & ROA & 21,792 & 0.0433 & 0.0402 & -2.5805 & 3.4322 \\
& ACCR & 21,803 & -0.0325 & -0.0308 & -17.8454 & 6.3014 \\
& CFLW & 21,792 & 0.0757 & 0.0724 & -4.2524 & 17.7807 \\
\hline Total & ROA & 53,570 & 0.0300 & 0.0279 & -137.1207 & 5.6160 \\
& ACCR & 53,581 & -0.0476 & -0.0347 & -458.1488 & 236.9833 \\
& CFLW & 53,570 & 0.0776 & 0.0663 & -236.9583 & 458.1488 \\
\hline
\end{tabular}

Table 8 provides results of persistence parameters in firms with negative and positive earnings, clustering by legal origin. This evidence confirms the rejection of our fourth hypothesis.

Table 8

Losses vs. profits. Fama-MacBeth regressions by accruals size and legal origin

\begin{tabular}{lrrrr}
\hline & Pool & \multicolumn{1}{c}{ French } & Geman & Scandinavian \\
\hline ROA & $0.286^{* *}$ & $0.325^{* *}$ & 0.413 & $0.223^{* * *}$ \\
& {$[0.093]$} & {$[0.12]$} & {$[0.32]$} & {$[0.093]$} \\
\hline ACCR & $0.227^{* *}$ & $0.405^{* * *}$ & 0.177 & $0.306^{* *}$ \\
& {$[0.090]$} & {$[0.12]$} & {$[0.11]$} & {$[0.10]$} \\
\hline CFLW & $0.255^{* *}$ & $0.409^{* * *}$ & $0.219^{* *}$ & $0.360^{* * *}$ \\
& {$[0.086]$} & {$[0.12]$} & {$[0.097]$} & {$[0.10]$} \\
\hline D & $-0.0223^{* * *}$ & $-0.0116^{* * *}$ & 0.0107 & $-0.0171^{*}$ \\
& {$[0.0051]$} & {$[0.0032]$} & {$[0.032]$} & {$[0.0093]$} \\
\hline dROA & -0.0743 & -0.209 & -0.0620 & -0.0608 \\
& {$[0.071]$} & {$[0.14]$} & {$[0.085]$} & {$[0.079]$} \\
\hline dACCR & -0.0809 & -0.0327 & 0.175 & -0.118 \\
& {$[0.092]$} & {$[0.059]$} & {$[0.16]$} & {$[0.11]$} \\
\hline dCFLW & -0.0823 & -0.0559 & 0.149 & $-0.149^{* *}$ \\
& {$[0.076]$} & {$[0.052]$} & {$[0.17]$} & {$[0.054]$} \\
\hline Constant & $0.0194^{* * *}$ & $0.00658^{* * *}$ & -0.0161 & $0.0245^{* * *}$ \\
& {$[0.0041]$} & {$[0.0010]$} & {$[0.032]$} & {$[0.0047]$} \\
\hline Observations & 38901 & 18832 & 2646 & 17423 \\
Number of groups & 11 & 11 & 11 & 11 \\
R-squared & 0.28 & 0.46 & 0.36 & 0.32 \\
\hline
\end{tabular}

Standard emors in brackets; *** $p<0.01$, ** $p<0.05, * p<0.1$

For positive earnings, a different persistence parameter can be observed between the French and the Scandinavian groups. In the French group, ROA, accruals and cash flows show a higher prsistence. Instead, there is no significant difference of persistence when firms get profits of losses, except for the Scandinavian group, but just for cash flows. In 
this case, when firms get losses, cash flows are less persitent, more or less at the same level as ROA. It means more variability in cash flows with the same stability in earnings and accruals, what would be indicating a very effective earnings smoothing policy.

\section{SUMMARY AND CONCLUSIONS}

Starting from the recent advances on earnings quality measures, our study provides evidence on the properties of earnings, cash flows and accruals in European private firms.

Some papers have studied the "accruals anomaly", following the seminal work of Sloan (1996). They usually support the existence of this anomaly, differentiating between low quality earnings and high quality earnings, depending on the size of accruals. The explanations of this fact are not so clear: accounting distortions, grow-related factors, accruals measurement, certain factors represented by special items... What is generally accepted is that the market mispricing of accruals is a sign of market inefficiency. So that, this question has important implications for fundamental valuation, as incorporating the accrual effect improves the accuracy of earnings forecasts in firms where earnings management occurs.

Previous evidence is mostly extracted from US listed companies. In our compilation, we gather just an international study in which accruals anomaly is tested in common law versus code law tradition countries, and this distinction proves to be relevant. So that, with all the rest evidence found in a common law tradition country, conclusions may not be so general. That is why we think that more work is needed before a complete picture of earnings, accruals and cash flows persistence emerges, and this paper tries to help complete the picture.

In a sample of 12,910 non quoted firms (all with necessary items available in Amadeus database) from 18 European countries, for the period 1995 to 2006, we have run several regressions to test our hypotheses on persistence of earnings and their two divisions: accruals and cash flows.

In Tables 1 and 2, we can get a first impression of the variables. For the whole sample, the average value of cash flows is higher than the average value of ROA. By country, cash flows and ROAs follow the same pattern, as only two countries are in the opposite situation, but the scarce number of firms taken may be causing the deviation (one firm from Luxembourg and two from Czech Republic). After ranking firm-years annually and assigning them in equal numbers to ten deciles (from extreme negative accruals in Decile 1 to extreme positive accruals in Decile 10), we can appreciate (Figure 1) that accruals are been used as an earnings smoothing tool.

Spearman correlations document stronger significant positive correlation between ROA and cash flows than between ROA and accruals; while the strongest significant correlation is the negative one between accruals and cash flows. These results are 


\section{B. Amor Tapia and M.T. Tascón Fernández}

consistent with previous evidence on this research line, even though only quoted companies had been tested. It suggests that a main effect of accruals is compensating extreme cash flows, confirming a general pattern of earnings smoothing.

In order to test our first and second hypotheses, we run three regressions which measure one-year-ahead persistence. Supporting previous evidence, results indicate concave relations with accruals for both ROA and cash flows. But contrary to Dechow and Ge's (2006) findings, persistence of ROA is higher than that of cash flows in extreme accruals.

We infer that, for European non quoted firms, earnings smoothing helps to approach business' regular incomes, even when accruals are extreme. There is no overreaction (in earnings management) trying to compensate extreme positive or negative cash flows. So that, a different behavior pattern of cash flows relative to earnings is documented in this type of firms.

Regressing ROA on its components, accruals and cash flows, we find a significant higher coefficient for cash flows, what attributes more predictive power to cash flows than to accruals (cash flow is the main value driver).

A possible different behaviour for positive versus negative earnings is tested in our fourth hypothesis. But contrary to our ex-ante expectations, no asymmetrical earnings management is found, suggesting that incentives to compensate losses in European non quoted firms are quite different from incentives in US quoted firms. In our opinion, non quoted firms can take advantage of losses, which allow them to get tax benefits, without suffering public companies' inconveniences. Lower levels of ownership dispersion make unnecessary the owners to get market information. Public information seems to obey just legal requirements. If earnings do not act as a signal for the market, it is no necessary to manage negative earnings in order to offer a better image of the firm.

Finally, information contained in Amadeus Database let us analize just three groups of countries as to legal origin: French, German and Scandinavian. For positive earnings, significant differences in persistence parameters are found between the French group (civil law tradition) and the Scandinavian group (closer to common law tradition), being French ROAs, accruals and cash flows more persistent. Instead, no significant differences are found when firms get losses, except for the Scandinavian group, and just for cash flows. In this case, when firms get losses, cash flows are less persitent, more or less at the same level as ROA. It means more variability in cash flows with the same stability in earnings and accruals, what would be indicating a very effective earnings smoothing policy. 


\section{REFERENCES}

Barth, M.E.; Beaver, W.H.; Hand, J.R.M. and Landsman, W.R. (1999). "Accruals, cash flows, and equity values", Review of Accounting Studies, 4 (3/4), pp. 205-229.

Beaver, W.H. (2002). "Perspectives on recent capital market research", The Accounting Review, 77 (2), pp. 453-474.

Burgstahler, D.C. and Dichev, I.D. (1997). "Earnings management to avoid earnings decreases and losses", Journal of Accounting and Economics, 24 (1), pp. 99126.

Burgstahler, D.C.; Hail, L. and Leuz, C. (2006). "The importance of reporting incentives: Earnings management in European private and public firms", The Accounting Review, 81 (5), pp. 983-1016.

Chan, K.; Chan, L.K.C.; Jegadeesh, N. and Lakonishok, J. (2006). "Earnings quality and stock returns", The Journal of Business, 79 (3), pp. 1041-1082.

Chan, K.; Jegadeesh, N. and Sougiannis, T. (2004). "The accrual effect on future earnings", Review of Quantitative Finance and Accounting, 22 (2), pp. 97-121.

Coppens, L. and Peek, E. (2005). "An analysis of earnings management by European private firms", Journal of International Accounting, Auditing and Taxation, 14 (1), pp. 1-17.

Dechow, P.M. (1994). "The role of accounting accruals", Journal of Accounting and Economics, 18 (1), pp. 3-42.

Dechow, P.M. and Dichev, I.D. (2002). "The quality of accruals and earnings: The role of accrual estimation errors", The Accounting Review, 77 (Suplement 1), pp. 35-59.

Dechow, P.M. and Ge, W. (2006). "The persistence of earnings and cash flows and the role of special items: Implications for the accrual anomaly", Review of Accounting Studies, 11 (2-3), pp. 253-296.

Desai, H.; Rajgopal, S. and Venkatachalam, M. (2004). "Value-glamour and accruals mispricing: One anomaly or two?", The Accounting Review, 79 (2), pp. 355-385.

Dichev, I.D. (2003). "Discussion of "The differential persistence of accruals and cash flows for future operating income versus future profitability"", Review of Accounting Studies, 8 (2-3), pp. 245-250.

Fairfield, P.M.; Whisenant, S. and Yohn, T.L. (2003). "The differential persistence of accruals and cash flows for future operating income versus future profitability", Review of Accounting Studies, 8 (2-3), pp. 221-243.

Francis, J.; Olsson, P. and Oswald, D.R. (2000). "Comparing the accuracy and explainability of dividend, free cash flow, and abnormal earnings equity value estimates", Journal of Accounting Research, 38 (1), pp. 45-70.

Hayn, C. (1995). "The information content of losses", Journal of Accounting and Economics, 20 (2), pp. 125-153. 
Healy, P.M. and Wahlen, J.M. (1999). "A review of the earnings management literature and its implications for standard setting", Accounting Horizons, 13 (4), pp. 365-383.

Hribar, P. and Collins, D.W. (2002). "Errors in estimating accruals: Implications for empirical research", Journal of Accounting Research, 40 (1), pp. 105-134.

Jones, J.J. (1991). "Earnings management during import relief investigations", Journal of Accounting Research, 29 (2), pp. 193-228.

La Porta, R.; López de Silanes, F.; Shleifer, A. and Vishny, R.W. (1997). "Legal determinants of external finance", Journal of Finance, 52 (3), pp. 1131-1150.

Leuz, C.; Nanda, D. and Wysocki, P.D. (2003). "Investor protection and earnings management: An international comparison", Journal of Financial Economics, 69 (3), pp. 505-527.

Lev, B. and Nissim, D. (2006). "The persistence of the accruals anomaly", Contemporary Accounting Research, 23 (1), pp. 193-226.

McNichols, M.F. (2002). "Discussion of 'The quality of accruals and earnings: The role of accrual estimation errors'", The Accounting Review, 77 (Suplement 1), pp. 61-69.

Palepu, K.G.; Healy, P.M. and Bernard, V.L. (2000). Business analysis and valuation. Using financial statements. Canada: South-Western Thomson Learning.

Penman, S.H. and Sougiannis, T. (1998). "A comparison of dividend, cash flow,and earnings approaches to equity valuation", Contemporary Accounting Research 15 (3), pp. 343-383.

Penman, S.H. and Zhang, X.-J. (2002). "Accounting conservatism, the quality of earnings, and stock returns", The Accounting Review, 77 (2), pp. 237-264.

Pincus, M.; Rajgopal, S. and Venkatachalam, M. (2007). "The accrual anomaly: international evidence", The Accounting Review, 81 (1), pp. 169-203.

Richardson, S.A.; Sloan, R.G.; Soliman, M.T. and Tuna, I. (2005). "Accrual reliability, earnings persistence and stock prices", Journal of Accounting and Economics, 39 (3), pp. 437-485.

Richardson, S.A.; Sloan, R.G.; Soliman, M.T. and Tuna, I. (2006). "The implications of accounting distortions and growth for accruals and profitability", The Accounting Review, 81 (3), pp. 713-743.

Sloan, R.G. (1996). "Do stock prices fully reflect information in cash flows and accruals about future earnings?", The Accounting Review, 71 (3), pp. 289315.

Subramanyam, K. and Venkatachalam, M. (2007). "Earnings, cash flows, and ex post intrinsic value of equity", The Accounting Review, 82 (2), pp. 457-481.

Xie, H. (2001). "The mispricing of abnormal accruals", The Accounting Review, 76 (3), pp. 356-373. 